\title{
Determinant of Export Success Factors: The Perception of Greek Food and Drink Export Companies
}

\author{
Athanasios Bizmpiroulas ${ }^{1}$ Konstantinos Rotsios $^{2}$ Georgios Kartsiotis $^{3}$
}

\begin{abstract}
:
The food and drink sector has traditionally played a very important role in Greece's economy. Recently, its importance has grown due to the economic crisis. In order to recover, the country's economy must become more internationally focused and the food and drink sector can play a crucial role in this effort. The main objective of this paper is to offer an insight into the perception of Greek food and drink exporters on key export success factors. A number of factors have been identified and examined in order to determine their impact on export performance. In particular, we examine the relationship between the company's export performance and a number of factors, such as the company's size, experience, dependency on exports, product quality, price and innovation. The findings from a sample of 95 Greek food and drink exporters are analyzed and presented. The paper offers theoretical insights on the determinants of food and drink export success. In addition, it has strong practical implications for enterprises in the food and drink sector currently involved in exports and the ones that plan to export. It is expected that the current economic situation will lead more Greek food and drink companies to attempt expansion into international markets. As they do, they need to have a clear view and understanding of the determinants of successful export performance.
\end{abstract}

Key Words: Food and Drink Sector, Exports, Key Success Factors

JEL Classification: F14, L83

\footnotetext{
${ }^{1}$ Perrotis College, American Farm School, Marinou Antipa 54, Thessaloniki 551 02, Greece, abizbi@perrotis.edu.gr

${ }^{2}$ Perrotis College, American Farm School, Marinou Antipa 54, Thessaloniki 551 02, Greece, krotsi@afs.edu.gr

${ }^{3}$ Perrotis College, American Farm School, Marinou Antipa 54, Thessaloniki 551 02, Greece, gkarts@afs.edu.gr
} 


\section{Introduction}

The loss of consumers' purchasing power due severe salary cuts and the current economic crisis in Greece has lead many Greek firms to seek customers in the international markets. While several studies have been conducted on Greek food exports, to the best of our knowledge no previous studies have examined the perception of Greek food and drink exporters regarding the determinants of their export success. The aim of this research is to analyze the perception of the Greek food and drink exporters on the determinants of export success factors, and to investigate their interrelation. The focus is on internal factors, since the external environment is volatile and firms have no control over it.

\section{Literature Review}

Export motives can be both internal and external. The motives related to the internal environment are, to increase profits, sales and customer base, to achieve economies of scale, to minimize risks that arise from the dependency on a single market, etc. (Hajidimitriou, 2003). The resource based paradigm suggests that a firm's export performance is based on firm related parameters, such as size, experience and the capabilities of the firm (Sousa et al., 2008).

There is no agreed definition of export performance as well as there is no a specific model to measure export performance (Stoian et al., 2011). According to Oliveira et al. (2012) researchers tend to analyze export performance either with models testing the export function, which is the export performance of the overall company exports, or with models testing the export venture, which examines only a single product or product line. Furthermore, when measuring export performance not a single performance indicator should be used (Diamantopoulos \& Kakkos, 2007). In addition combinations of measurements will increase the accuracy of the reading related to export performance (Shoham, 1998).

Firm size as a determinant of export success, is one of the characteristics often examined in literature (Sousa et al., 2008, Zaiem \& Zghidi, 2011). The findings related to the firm's size and its impact on exports is contradictory. Some studies suggest that size has positive impact on export performance (Larimo, 2013, Shinkle $\&$ Kriauciunas, 2010). On the contrary, other findings suggest that firm size has not a significant relationship with export performance (Stoian et al., 2011, Zaiem \& Zghidi, 2011).

Export experience can be indicated by the number of years an organization is exporting (Maurel, 2009). According to research cited from Zaiem and Zghidi (2011) another indicator of export experience can be the number of countries firms export to, and the firms' age. Results on the impact of export experience are 
contradictory too. Some argue that there is relationship between firms experience (including firms age as an indicator) and export performance (Nagy \& Berács 2012, Majocchi et al., 2005). However, others suggest that there is no significant relationship between experience and export performance (Mavrogiannis et al. 2008, Zaiem \& Zghidi, 2011).

Another export performance determinant is the firm's commitment towards exports. The top management's commitment and the allocation of resources to export activities, result to better export performance. In addition it enhances the creation of an "export oriented culture" within the organization (Lages et al., 2008). There is an agreement among researchers on the positive relationship between export performance and commitment (Stoian et al., 2010, Navarro et al., 2009).

High quality products can lead to the creation of an image of a superior product, and can result to higher earnings (Boeche \& Cruz, 2010). Other researchers, link positively product quality and export performance (Leonidou et al., 2002, Curzi \& Olper, 2012). Fisher (2010) suggests that while quality can be positively be related to export performance in some industries and target countries, in others, its relationship was not found to be significant.

Price is also an important factor in export activities. However, in a literature review from Sousa et al., (2008) mixed results are presented, some studies suggest a significant positive relationship between export performance and price was found, while others presented negative results. A positive relation was also found by Leonidou et al., (2002). In addition, competition uncertainty about foreign markets can lead export firms to adopt price changes, even though this action does not have an impact on export performance (Obadia 2013).

Innovation and its impact on export performance is often examined in literature. Product innovation can contribute positively to economic performance (Lages et al., 2009). Boso et al. (2013) found that the relationship between firm innovation and export performance is stronger when the environment in the target market is more competitive, and when customers in the exporting markets have more dynamic needs.

\section{Methodology}

In this study, the performance indicators chosen are, the percentage of the total production that is being exported, and the percentage of the value of exports to total sales. The focus is on the overall firm's results rather than product or line specific results. 
A questionnaire was sent electronically to 1050 firms listed in the directory of the Pan-Hellenic Exporters Association. Of the 767 firms that received the emails, 95 usable were returned, a response rate of $12.4 \%$, comparable to similar research that targets senior executives, and usually has a response rate between $10 \%$ and $12 \%$ (Hambrick, Geletkanyeq \& Fredrickson 1993). Because of the complexity of the questionnaire it is assumed that the respondents were either the owners or a senior executive.

\section{Results}

It should be noted that with the exception of the subsector, the size of the firm, the years as active exporters, the percentages of production exported and percentages of sales and the question about the application of quality assurance system, all other results are related only to the perception of Greek food and drink exporters.

\subsection{Export Performance}

In order to examine the determinants and their impact on export performance, six export performance groups were created. The groups are defined as:

-1-25\% of Production Exported \& 1-20 \% of Sales from Exports: Low-Low -1-25 \% of Production Exported \& 21-40 \% of Sales from Exports: Low-High -26-50 \% of Production Exported \& 21-40 \% of Sales from Exports: Medium-Low -51-75 \% of Production Exported \& 41-60 \% of Sales from Exports: Medium-High -76-100 \% of Production Exported \& 61-80 \% of Sales from Exports: High-Low -76-100\% of Production Exported \& 81- $00 \%$ of Sales from Exports : High-High

Figure 1 depicts the frequencies for each of the export performance categories. The largest percentage of the firms belong to the Low-Low group $(43.2 \% n=41)$. For the majority of Greek companies in our sample, exports are not their main business activity. 
Figure 1. Frequency in every export performance category

$$
\text { Export Performance: }
$$

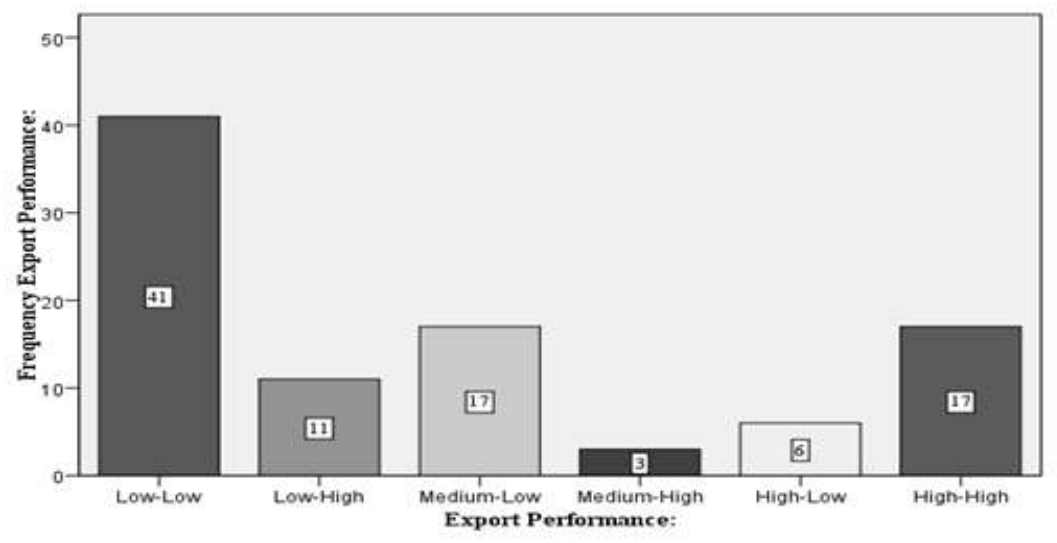

A weak, negative correlation exists between product innovation and performance. This could be due to the fact that international customers might have associated Greek food and drink products with a more traditional character and do not expect or value innovation in them.

There is a weak, positive correlation between the perceived importance of experience and export performance, which means that the higher the perceived importance of experience is, the higher the export performance. That could be due to the fact that experience is often related to better understanding of the export related processes.

Table 1. Correlations of Export Performance

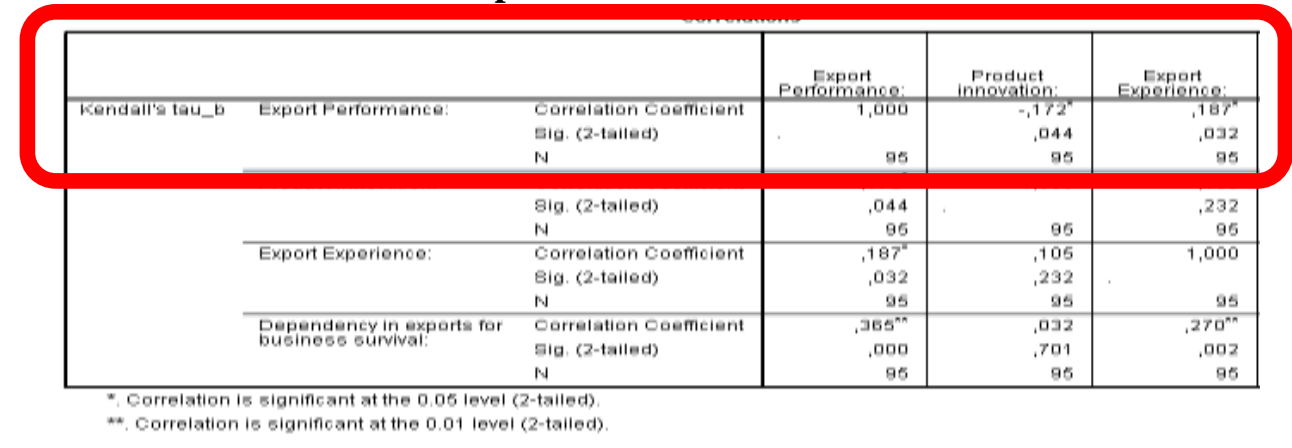




\subsection{The Firm's Size}

The following table shows the size of the firms and ranks them in regards to their export performance. For the purposes of this study the firms' size is determined by the number of employees. The categories formed are (adopted by the European Commission, 2014):

- 1-9 employees - micro firms: A

- $\quad$ 10-50 employees - small firms: B

- 51-100 employees -medium firms: C

- Over 100 employees - medium firms: D

The largest percentage $36.8 \%(n=35)$ is in category A, followed by B $(31.6 \% n=30)$. The majority of Greek firms in our sample are either micro or small in size. Some of the most interesting findings are that in the higher export performance categories the micro and small firms seem to have more representatives.

\section{Table 2. Personnel Frequency Table}

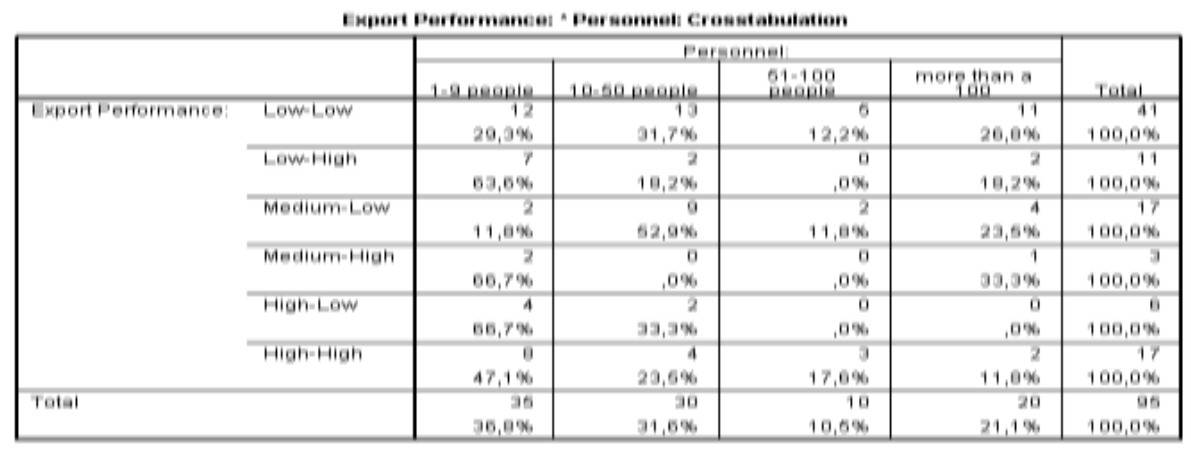

The size of a firm has a weak, negative correlation with the application of quality assurance systems (Table 3). The smaller the size of the firm is, the higher are the chances are that they do not to apply quality assurance systems. Apparently small firms can not undertake the additional costs associated with the application of these systems. 
Table 3. Correlation between Personnel and Application of Quality Assurance System

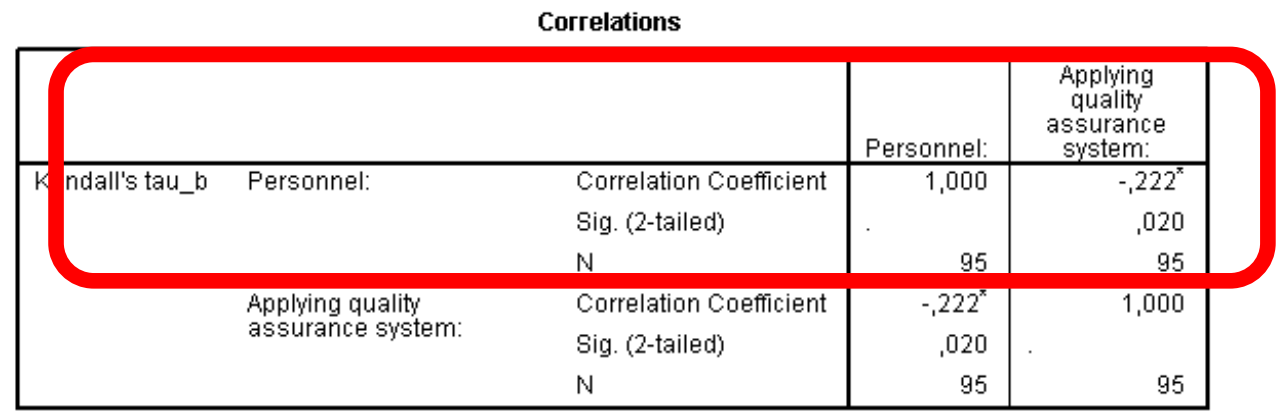

${ }^{*}$. Correlation is significant at the 0.05 level (2-tailed).

Price appears to have a weak, positive correlation with firm's size; the larger the size of the firm the higher the importance of price is. Larger firms try to achieve economies of scale and consider price to be as important to enter new markets or as a source of competitive advantage. Smaller firms cannot achieve economies of scale, aim to premium markets and price is not of major importance to them.

The size of the firm is also related to the firm's perception about Greece as a country of origin, being an advantage or not. There is a weak, positive correlation between the two. That means that the larger firms perceive Greece's image as an advantage. Large firms rely on the "Greek traditional" character of their products. On the other hand, smaller firms might focus more on product attributes and differentiation.

There is a weak, positive correlation between the firm's size and the existence of an export department. This is as expected, since larger firms can allocate resources to exports, while often in smaller ones employees play various roles.

The weak positive correlation with the highest significance and correlation value is the one between the firm's size and the actual export experience. The larger firms in the sample, started exporting earlier than smaller ones for various reasons, such the saturation of the local market, increase profits etc. 


\section{Table 4. Personnel Correlations}

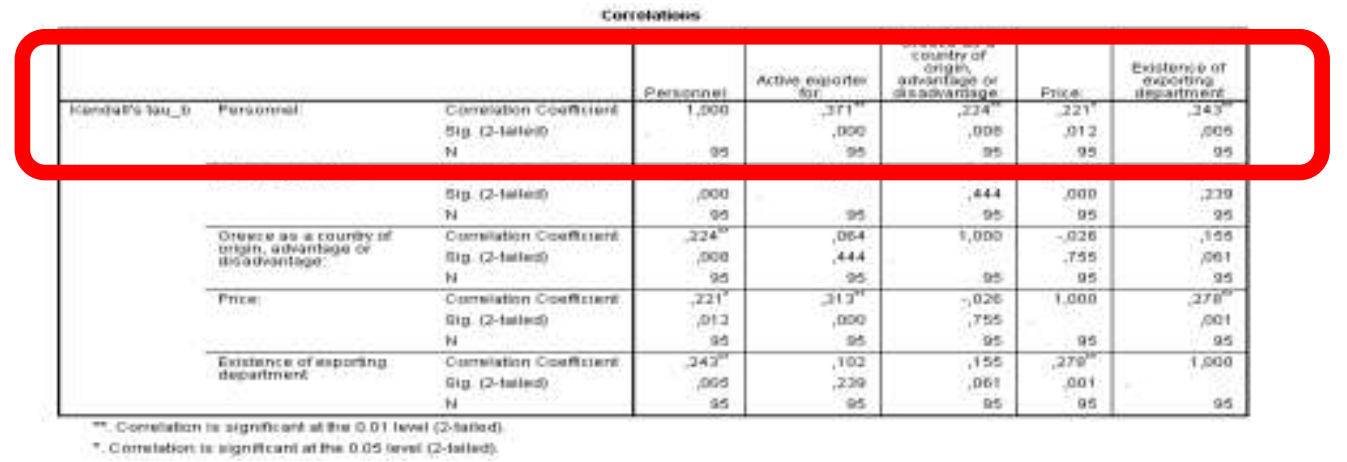

There is no correlation between the firm's size and export performance. Size does not ensure the success of the export activities of the company, but at the same time it is not a limiting factor.

\subsection{The Firm's Actual Export Experience}

Next, the actual exporting experience and its relation to export performance is examined. The years firms have been active in exports are used as an indicator of export experience. Four categories were formed:

- $\quad 1-5$ years: $\mathrm{E}$

- 6-10 years: $\mathrm{F}$

- $\quad 11-15$ years, : G

- 16 years and over: $\mathrm{H}$.

Most of the respondents in our sample have a long export experience, but there are new entries in the export market. There seems to be a concentration mainly in the Low-Low and followed by High-High export performance groups.

Table 5. Export Performance with Actual Experience

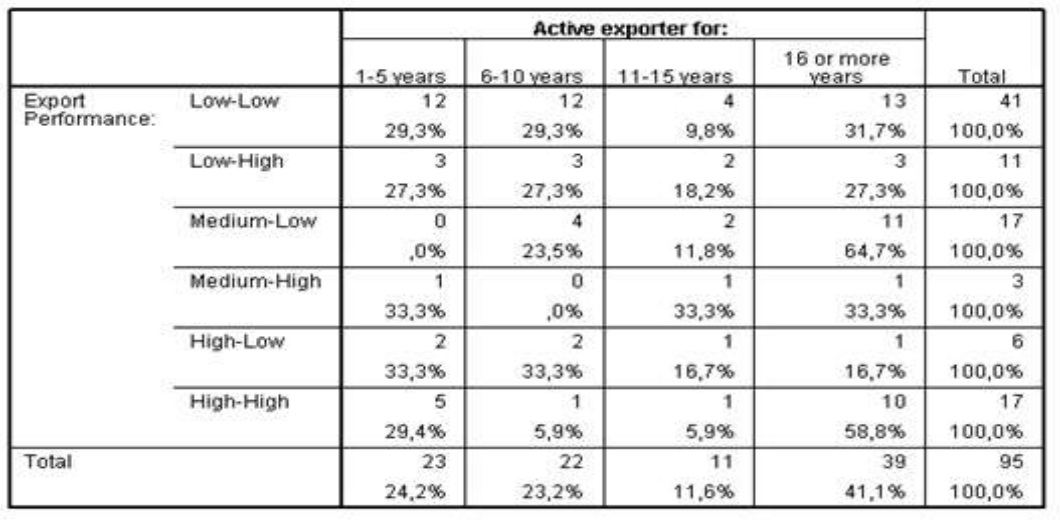


Product innovation has a weak negative correlation, the more the export experienced a firm is, the less it perceives innovation to be important. Younger firms try to cope with competition with product innovation, while older exporters might sell products that are more traditional and less innovative.

Next, the relation between the firms' actual experience and the difficulty they faced to enter their main market was investigated and a weak negative correlation was found. In this case, export experience is measured by years of exports. Firms with many years of export experience faced more difficulty to enter their main market. Apparently, firms with less export experience, find it easier to enter into new markets. This could be due to new trade agreements, changes in consumers' preferences or recent market opportunities, (eg the Greek yogurt), which increased export opportunities for other Greek food and drink products as well. Moreover, it could be an indicator of changes in business philosophy, and the quality of Greek food and drink products.

A weak, negative correlation exists between export experience and both the international consumers' income and their sociocultural level. The significance is higher for the sociocultural status variable. These weak, negative correlations mean that older firms started exporting to lower income and sociocultural level consumers. Apparently, the older exporters, exported lower quality products, and did not meet the demands of consumers with higher income and socio-cultural status. On the contrary, newer exporters aim at higher income and the socio-cultural level consumers. Greek firms recognized the current consumer trends such as foodies (individuals with higher income and of high sociocultural status).

\section{Table 6. Actual Experience Negative Correlations}

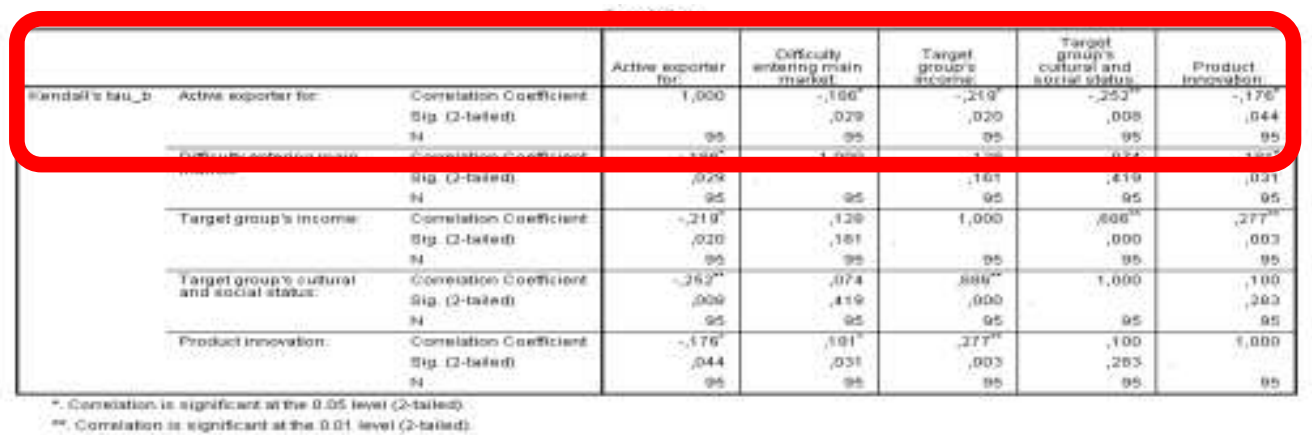

There is a weak positive correlation between the actual experience (years) and the perceived importance of export experience; the more a firm's actual export experience is, the more it considers experience to be important. An explanation is that firms have developed a better understanding of export activities and export 
experience and the benefits they have gained from it, or that they realize more and more the importance of exports and their complexity.

There is a weak, positive correlation between export experience and the perceived importance of price. The more experienced a firm is, the more important it considers price to be. This is in agreement with the consumers' sociocultural and income level findings analyzed earlier. Younger firms aim at higher income and sociocultural status customers and do not perceive the price of their products so important, while the more experienced ones aim mainly to medium income and sociocultural level ones, and consider price to be important.

\section{Table 7. Actual Experience Positive Correlations}

correlations

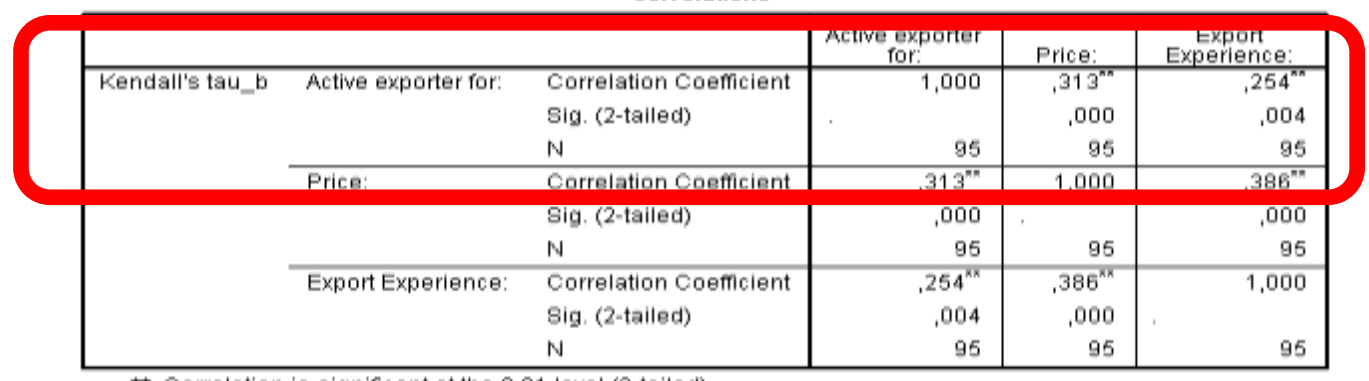

*t, Correlation is significant at the 0.01 level (2-tailed).

From the sample available no correlation was found between actual export experience and export performance. That means that experience is not a limiting factor for export success.

\subsection{The Firm's Perception on Commitment to Exports}

The degree of export dependency for the business' survival is examined in this section. It is theorized that dependency leads to commitment, and thus dependency is equal to commitment. The following categories were formed, to depict the level of importance for a number of variables (commitment to exports, product quality, price and innovation).

\footnotetext{
- $\quad$ Very unimportant: 1

- $\quad$ Quite unimportant: 2

- $\quad$ Slightly unimportant: 3

- $\quad$ Neither/neutral: 4

- $\quad$ Slightly important, henceforward category 5

- $\quad$ Quite important: 6

- $\quad$ Very important: 7
} 
As shown on Table 8, the higher the export performance group, the higher the perceived importance on exports for the firm's survival. The majority of the respondents consider export dependency as being "slight" important for export success.

\section{Table 8. Export Performance and Commitment}

\begin{tabular}{|c|c|c|c|c|c|c|c|c|}
\hline & & \multicolumn{6}{|c|}{ Dependency in exports for business survwal: } & \multirow[b]{2}{*}{ Total } \\
\hline & & $\begin{array}{l}\text { Very } \\
\text { unimpoitant }\end{array}$ & $\begin{array}{l}\text { Slightly } \\
\text { unimportant }\end{array}$ & Neither & $\begin{array}{c}\text { Slighty } \\
\text { important }\end{array}$ & $\begin{array}{l}\text { Quine } \\
\text { important }\end{array}$ & Verr imoortant & \\
\hline \multirow{12}{*}{$\begin{array}{l}\text { Export } \\
\text { Performance: }\end{array}$} & \multirow[t]{2}{*}{ Low'Low } & 4 & 6 & 14 & 10 & 4 & 3 & 41 \\
\hline & & $9,8 \%$ & $14,6 \%$ & $34,1 \%$ & $24,4 \%$ & $9,8 \%$ & $7,3 \%$ & $100,0 \%$ \\
\hline & \multirow[t]{2}{*}{ Low-High } & 1 & 1 & 2 & 3 & 2 & 2 & 11 \\
\hline & & $9,1 \%$ & $9,1 \%$ & $18,2 \%$ & $27,3 \%$ & $18,2 \%$ & $18,2 \%$ & $100,0 \%$ \\
\hline & \multirow[t]{2}{*}{ Medium-Low } & 0 & 1 & 3 & 10 & 1 & 2 & 17 \\
\hline & &, $0 \%$ & $59 \%$ & $17,6 \%$ & $58,8 \%$ & $5,9 \%$ & $11,8 \%$ & $100,0 \%$ \\
\hline & \multirow[t]{2}{*}{ Medium-High } & 1 & 0 & 0 & 0 & 0 & 2 & 3 \\
\hline & & $33,3 \%$ & $.0 \%$ & $.0 \%$ & $.0 \%$ & $.0 \%$ & $66,7 \%$ & $100,0 \%$ \\
\hline & \multirow[t]{2}{*}{ High-Low } & 0 & 0 & 1 & 2 & 3 & 0 & 6 \\
\hline & &, $0 \%$ & $.0 \%$ & $16,7 \%$ & $33,3 \%$ & $50,0 \%$ &, $0 \%$ & $100,0 \%$ \\
\hline & \multirow[t]{2}{*}{ High-High } & 0 & 1 & 1 & 3 & 4 & 8 & 17 \\
\hline & &, $0 \%$ & $59 \%$ & $5,9 \%$ & $17,6 \%$ & $23,5 \%$ & $47,1 \%$ & $100,0 \%$ \\
\hline \multirow{2}{*}{\multicolumn{2}{|c|}{ Total }} & 6 & 9 & 21 & 28 & 14 & 17 & 95 \\
\hline & & $6,3 \%$ & $9,5 \%$ & $22,1 \%$ & $29,5 \%$ & $147 \%$ & $17,9 \%$ & $100,0 \%$ \\
\hline
\end{tabular}

A weak, positive correlation between export commitment and export performance was found. The more committed a firm is to exports, the higher its export performance will be. However a stronger correlation was expected. Apparently, there are many exogenous to the firm factors that affect export success and hinder export performance, such as cost competitiveness, insurance costs, energy costs and high financing costs (Bizmpiroulas \& Rotsios 2014).

A weak positive correlation exists between the firm's commitment to exports and the perceived importance of export experience. The higher the commitment is, the higher the perceived importance of export experience, suggesting that Greek exporters understand the value of experience for export success.

Communication with trade partners and export commitment, have a weak positive correlation. The higher the commitment is, the more important communication with trade partners is perceived to be. Effective communication is a key to long term partnerships. For that reason, successful communication is crucial for firm's export success and survival.

A weak, positive correlation exists between export commitment and participation in international trade fairs. The more committed a firm is towards exports; the more important it considers participation in international fairs to be. International trade 
fairs can be the means to promote and introduce products to new markets, as well as to identify potential business partners.

The firm's commitment to exports with the perceived importance of an exporting department has a weak, positive correlation. The more committed a firm is to exports; the more important it considers the existence of an export department to be. This result was expected, since an export department leads to an increased export performance, as observed in the export performance category.

Finally, a weak positive correlation exists between firm's commitment to exports and the perceived importance of being consistent in trade agreements with partners. This result indicates that the more committed to exports a firm is, the more important consistency in agreements is. Consistency emerges as a key factor when it comes to long term business deals.

\section{Table 9. Commitment Correlations}

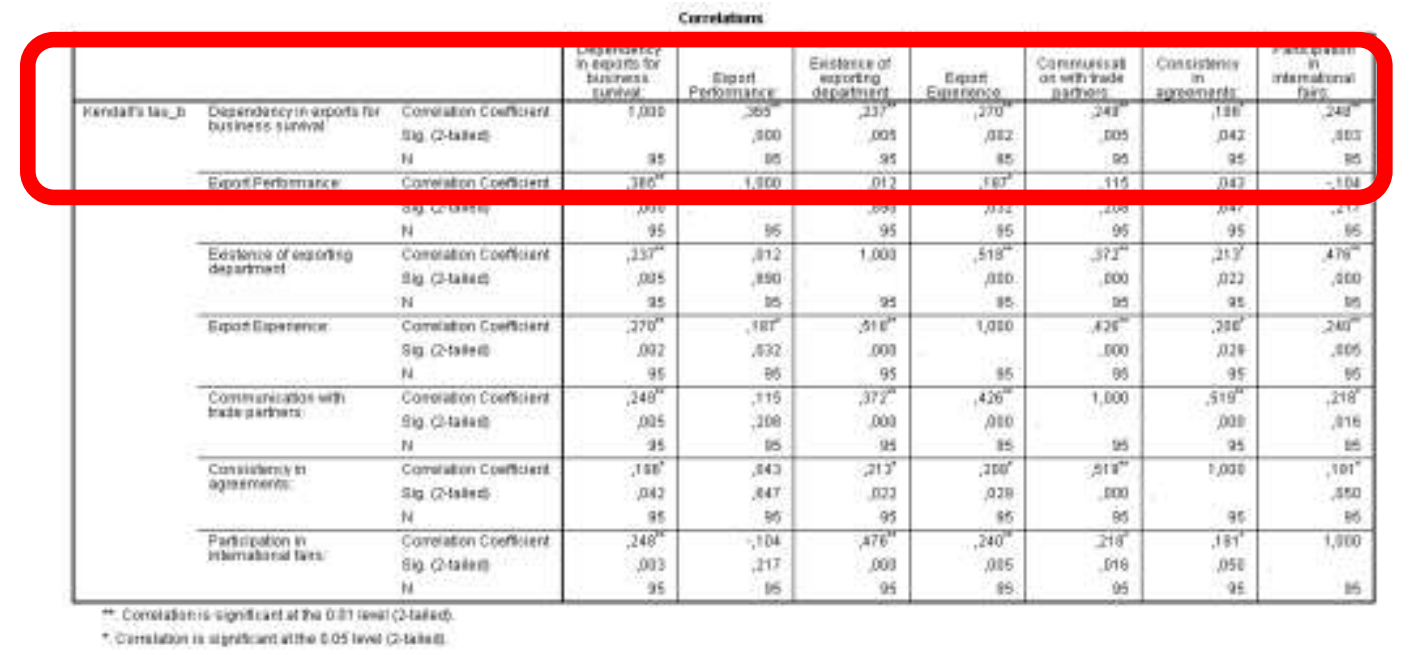

From all variables examined in literature, the one with the most straightforward result is the positive relationship between export commitment and export performance. Our results are in agreement, showing a weak positive correlation. 


\subsection{The Firm's Perception on Product Quality}

Product quality is one of determinants that affect export performance. In relation to quality the majority of the respondents, $(84.2 \% \mathrm{n}=80)$ considers quality as very important. Furthermore, quality is considered as very important for all the exporters no matter their export performance.

Table 10. Export Performance with Product Quality

\begin{tabular}{|c|c|c|c|c|c|c|c|c|}
\hline \multicolumn{9}{|c|}{ Expont Performances: 'Pricer Crosstabutotion } \\
\hline & & \multicolumn{6}{|c|}{ Price: } & \multirow[b]{2}{*}{ Tot: } \\
\hline & & $\begin{array}{l}\text { Quite } \\
\text { unimpongant }\end{array}$ & $\begin{array}{l}\text { Blighty } \\
\text { uaimportam }\end{array}$ & Neither & slightly & $\begin{array}{l}\text { Qube } \\
\text { impontant }\end{array}$ & Very & \\
\hline \multirow{12}{*}{$\begin{array}{l}\text { Export } \\
\text { Peisomance: }\end{array}$} & \multirow[t]{2}{*}{ Low-Lod } & 0 & 1 & 2 & 8 & 12 & 18 & 41 \\
\hline & & $.0 \%$ & $2,4 \%$ & $4,9 x$ & $19.5 \%$ & $29,9 \%$ & 43,96 & $100,0 \%$ \\
\hline & \multirow[t]{2}{*}{ Low.High } & 0 & 1 & 0 & 4 & 3 & 3 & 11 \\
\hline & & $.0 \%$ & $8,1 \%$ & $.0 \%$ & $35,4 \%$ & $27,3 \%$ & $27,3 \%$ & 300,03 \\
\hline & \multirow[t]{2}{*}{ Nedium-LoN } & 0 & 0 & 1 & 4 & 4 & 8 & 17 \\
\hline & &, $0 \%$ & $.0 x$ & 5,95 & $23,5 \%$ & $23,5 \%$ & $47,1 \%$ & $100,0 \%$ \\
\hline & \multirow[t]{2}{*}{ Medium-High } & 1 & 0 & 0 & $t$ & 0 & 1 & 3 \\
\hline & & 33,34 & $\alpha x$ &, $0 \%$ & $33,3 \%$ & $.0 \%$ & $33,3 \%$ & $100,0 \times$ \\
\hline & \multirow[t]{2}{*}{ High-LoN } & 0 & 0 & 1 & 3 & 1 & 1 & 8 \\
\hline & & .95 & $.0 x$ & $16,7 \%$ & $50,0 \%$ & $16,7 \%$ & $16,7 \%$ & 100,0 s. \\
\hline & \multirow[t]{2}{*}{ High-High } & 0 & 1 & 2 & 4 & 4 & 6 & 17 \\
\hline & & $.0 \%$ & $8.8 x$ & 11,83 & $23,5 \%$ & $23,5 \%$ & $36,3 \%$ & 100,03 \\
\hline \multirow{2}{*}{\multicolumn{2}{|c|}{ Total }} & 1 & 3 & B & 24 & 24 & 37 & 95 \\
\hline & & $1,1 \%$ & $0,2 \%$ & 0,35 & $25,3 x$ & $25,3 \%$ & $38,6 \%$ & 100,03 \\
\hline
\end{tabular}

A weak, positive correlation was found between quality and participation in international trade fairs. The more important quality is perceived to be, the more important the participation in trade fairs is. That could be because, high quality products can be key to success, when attending international fairs, since potential trade partners are coming in contact with the firms products. An additional reason that there is increased competition in the international trade fairs and higher quality products can have an advantage against the competition.

Another weak positive correlation exists between product quality and consistency in trade agreements with partners: the more important quality is perceived, the more important consistency in agreements is considered to be. It is important that products are of consistent quality as agreed between the business partners.

There is a weak positive correlation between quality and the PGI and PDO schemes. The more important firms consider quality to be, the more important they consider the PGI and PDO schemes. These schemes have been established by the EU and are presented under the title Quality Policy in the European Commission's website (2014). This indicates that these products are connected to a large extend, to product quality. 
A significant weak correlation between product quality and quality assurance system was found. The more important the product quality is perceived to be, the more important the quality assurance system is. This result was expected, since quality assurance systems; aim to ensure consistent product quality. However it should be noted that a stronger correlation was expected because of the above fact.

Lastly, a significant weak positive correlation exists between product quality and communication with trade partners, which indicates that the more important the quality, the more important the communication is. This can be explained by aspects, like the importance of the products' traceability, as well as the ability to understand the product quality trade partners' request.

\section{Table 11. Product Quality Correlations}

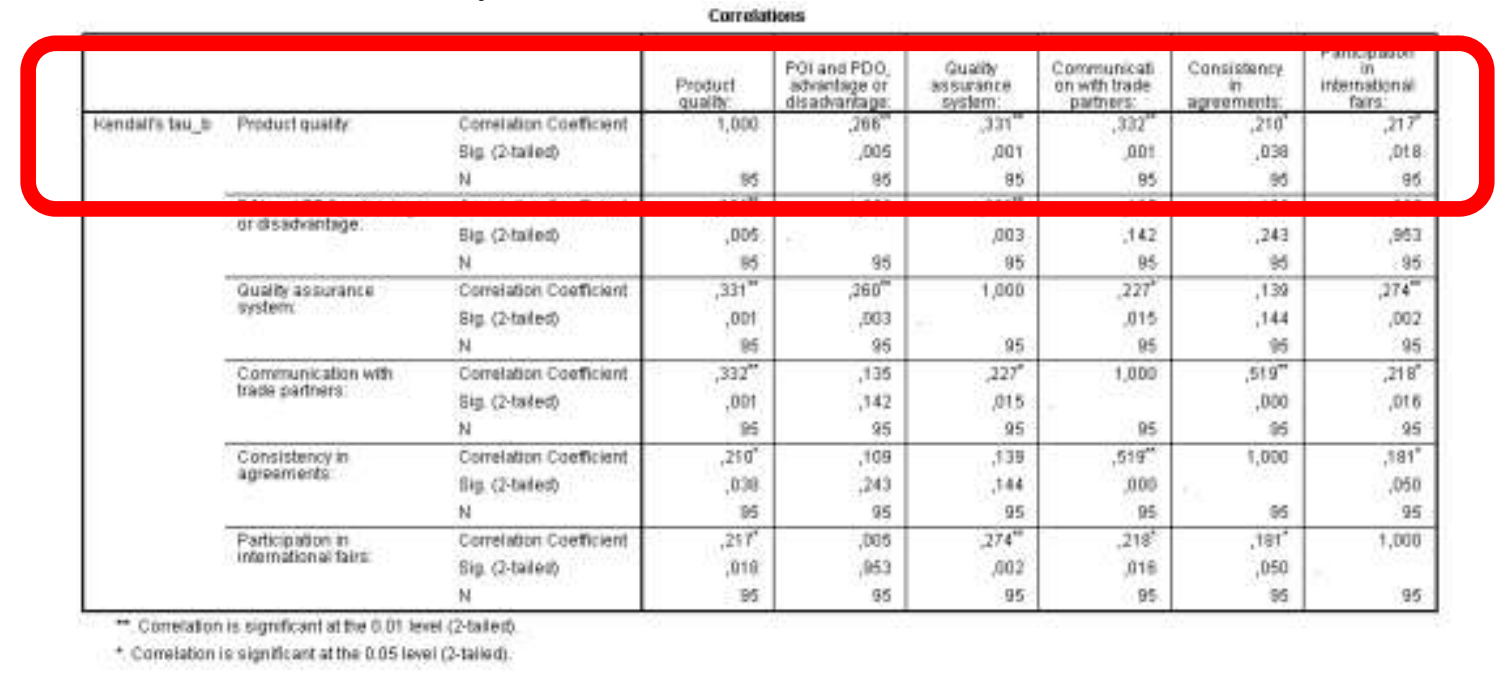

Most studies suggest a positive relationship between quality and its relation to export performance. However, some suggest that quality itself is not enough, or that quality is unimportant in some industries. In this case there is no correlation between qualities export performance.

\subsection{The Firm's Perception on Price}

In this section the perception of Greek food and drink exporters is examined in regards to price. In addition the relationship between price and export performance is examined.

The vast majority of the respondents consider price important. The table below depicts the cross tabulation between export performance and price. For the higher 
export performance categories, price is not as important, either due to the market segments Greek exporters aim to, or because they Greek firms have established a strong brand name in the export markets.

\section{Table 12. Export Performance with Price}

\begin{tabular}{|c|c|c|c|c|c|c|c|c|}
\hline \multicolumn{9}{|c|}{ Export Performance: : Price: Crosstabulation } \\
\hline & & \multicolumn{6}{|c|}{ Price: } & \multirow[b]{2}{*}{ Total } \\
\hline & & $\begin{array}{c}\text { Quite } \\
\text { unimeorlant }\end{array}$ & $\begin{array}{c}\text { Sightly } \\
\text { unimportant }\end{array}$ & Neither & $\begin{array}{l}\text { Sightth } \\
\text { important }\end{array}$ & $\begin{array}{c}\text { Quite } \\
\text { important }\end{array}$ & $\begin{array}{c}\text { Very } \\
\text { important } \\
\end{array}$ & \\
\hline \multirow{12}{*}{$\begin{array}{l}\text { Eyport } \\
\text { Periomance: }\end{array}$} & \multirow[t]{2}{*}{ LOW'LOW } & 0 & 1 & 2 & 8 & 12 & 18 & 41 \\
\hline & & $0 \%$ & $2,4 \%$ & $4,9 \%$ & $19,5 \%$ & $29,3 \%$ & $43,9 \%$ & $100,0 \%$ \\
\hline & \multirow[t]{2}{*}{ Low-High } & 0 & 1 & 0 & 4 & 3 & 3 & 11 \\
\hline & & $.0 \%$ & $9,1 \%$ & $.0 \%$ & $36,4 \%$ & $27,3 \%$ & $27,3 \%$ & $100,0 \%$ \\
\hline & \multirow[t]{2}{*}{ Medium-Low } & 0 & 0 & 1 & 4 & 4 & 8 & 17 \\
\hline & & $.0 \%$ & $.0 \%$ & $5,9 \%$ & $23,5 \%$ & $23,5 \%$ & $47,1 \%$ & $100,0 \%$ \\
\hline & \multirow[t]{2}{*}{ Medium-High } & 1 & 0 & 0 & 1 & 0 & 1 & 3 \\
\hline & & $33,3 \%$ &, $0 \%$ & $.0 \%$ & $33,3 \%$ & $.0 \%$ & $33,3 \%$ & $100,0 \%$ \\
\hline & \multirow[t]{2}{*}{ High-Low } & 0 & 0 & 1 & 3 & 1 & 1 & 6 \\
\hline & & $.0 \%$ & $0 \%$ & $16,7 \%$ & $50,0 \%$ & $16,7 \%$ & $16,7 \%$ & $100,0 \%$ \\
\hline & \multirow[t]{2}{*}{ High-High } & 0 & 1 & 2 & 4 & 4 & 6 & 17 \\
\hline & & $.0 \%$ & $5,9 \%$ & $11,8 \%$ & $23,5 \%$ & $23,5 \%$ & $35,3 \%$ & $100,0 \%$ \\
\hline \multirow{2}{*}{\multicolumn{2}{|c|}{ Total }} & 1 & 3 & 6 & 24 & 24 & 37 & 95 \\
\hline & & $1,1 \%$ & $32 \%$ & $6,3 \%$ & $25,3 \%$ & $25,3 \%$ & $38,9 \%$ & $100,0 \%$ \\
\hline
\end{tabular}

A weak, positive correlation exists between price and participation in international trade fares. This shows that the more important the price is perceived to be, the more important participation in trade fairs is considered to be. An explanation is that since firms want to attract new trade partners or customers by participating in international trade fairs, they perceive price as an aspect that can be of importance to them and is regarded as a competitive advantage.

A weak, positive correlation exists between price and quality assurance systems. The more important the price is, the more important the quality assurance system is. Quality assurance systems are an extra cost that is included into the final price, and that the application of quality assurance system justifies higher prices.

There is a significant, weak positive correlation between price and the existence of an export department as well as export experience. The more important the price is perceived to be, the more important the export department and export experience are considered to be. One explanation is that the existence of an export department and export experience, allow firms to more efficiently aim to specific markets with price related strategies, or to take advantage of the experience to target markets in which price is considered to be less important. 


\section{Table 13. Price Correlations}

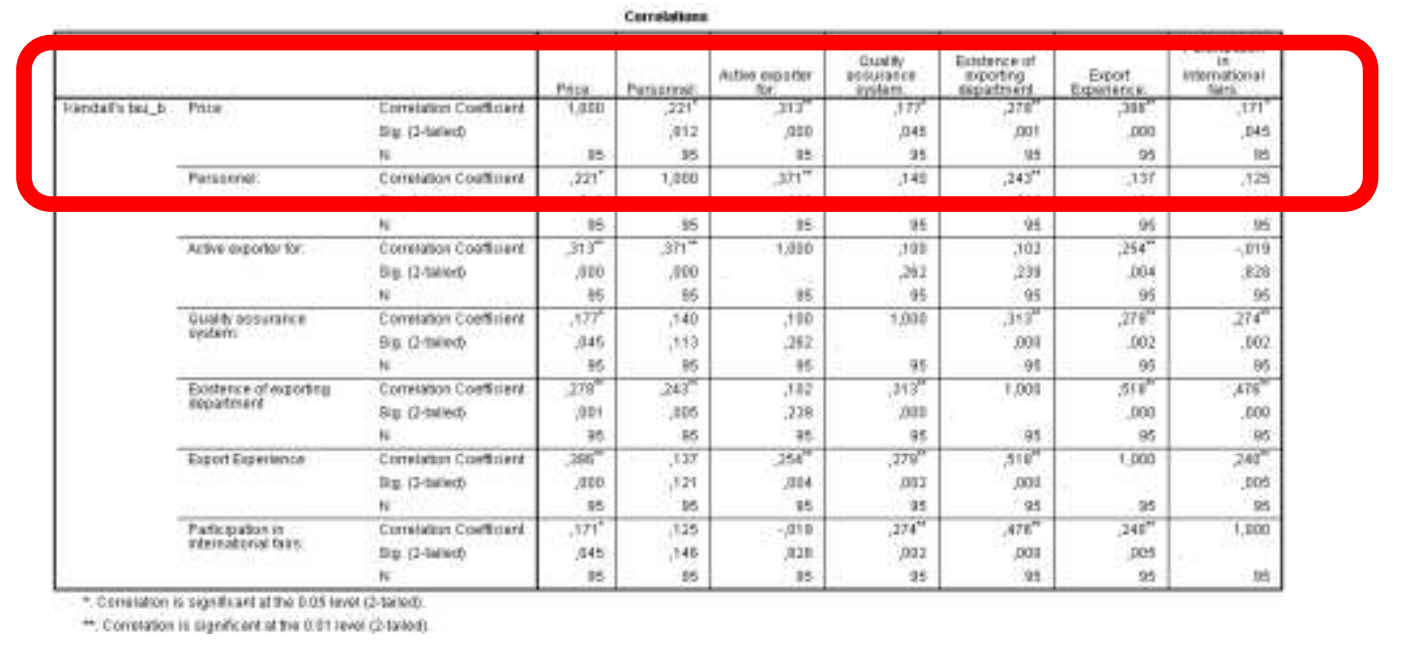

There are mixed results in literature, regarding price and export performance. In the case of the Greek food and drink exporters a correlation between price and export performance does not exist.

\subsection{The Firm's Perception on Product Innovation}

According to literature, product innovation is one of the determinants of export performance. In general it is perceived important from the majority of the firms in our sample $(87.4 \% \mathrm{n}=83)$. What is interesting is that in the lower export performance groups, innovation is considered to be more important than in the high export performance groups. 
Table 14. Export Performance with Product Innovation

\begin{tabular}{|c|c|c|c|c|c|c|c|c|}
\hline \multicolumn{9}{|c|}{ Export Performance: ' Product innovationc Crosstabulation } \\
\hline & & \multicolumn{6}{|c|}{ Product innowation: } & \multirow[b]{2}{*}{ Total } \\
\hline & & $\begin{array}{c}\text { Quite } \\
\text { unimpestant }\end{array}$ & $\begin{array}{c}\text { Slightty } \\
\text { unimporfant }\end{array}$ & Neithet & $\begin{array}{l}\text { Slogty } \\
\text { impoctant }\end{array}$ & $\begin{array}{l}\text { Quite } \\
\text { imanoriant }\end{array}$ & $\begin{array}{l}\text { Very } \\
\text { importart }\end{array}$ & \\
\hline \multirow{12}{*}{$\begin{array}{l}\text { Egpon } \\
\text { Performance: }\end{array}$} & \multirow[t]{2}{*}{ LONFLON } & 0 & 1 & 3 & 9 & 11 & 17 & 41 \\
\hline & &, $0 \%$ & $2,4 \%$ & $7,3 \%$ & $22,0 \%$ & $26,8 \%$ & $41,5 \%$ & $100,0 \%$ \\
\hline & \multirow[t]{2}{*}{ Lou-High } & 0 & 0 & 0 & 5 & 4 & 2 & 11 \\
\hline & &, $0 \%$ &, $0 \%$ & $.0 *$ & $45,5 \%$ & $36,4 \%$ & $18,2 \%$ & $100,0 \%$ \\
\hline & \multirow[t]{2}{*}{ Medium-LOW } & 0 & 2 & 1 & 3 & 4 & 7 & 17 \\
\hline & &, $0 \%$ & $11,8 \%$ & $5,9 \%$ & $17,6 \%$ & $23,5 \%$ & $41,2 *$ & $100,0 \%$ \\
\hline & \multirow[t]{2}{*}{ Medium-High } & 0 & 0 & 1 & 0 & 2 & 0 & 3 \\
\hline & &, $0 \%$ &, $0 \%$ & $33,3 x$ & $.0 \%$ & $66,7 \%$ & $.0 \%$ & $100,0 \%$ \\
\hline & \multirow[t]{2}{*}{ High-Low } & 0 & 0 & 1 & 1 & 3 & 1 & 8 \\
\hline & &, $0 \%$ &, $0 \%$ & $16.7 \%$ & $15,7 \%$ & $50,0 \%$ & $16,7 \%$ & $100,0 \%$ \\
\hline & \multirow[t]{2}{*}{ High-High } & 1 & 0 & 2 & 7 & 4 & 3 & 17 \\
\hline & & $5,9 \%$ & $0 \%$ & $11,8 \%$ & $41,2 \%$ & $23,5 \%$ & $17.6 \%$ & $100,0 \%$ \\
\hline \multirow{2}{*}{\multicolumn{2}{|c|}{ Total }} & 1 & 3 & 8 & 25 & 28 & 30 & 95 \\
\hline & & $1,1 \%$ & $3,2 \%$ & $8,4 \%$ & $26,3 \%$ & $29,5 \%$ & $31,6 \%$ & $100,0 \%$ \\
\hline
\end{tabular}

A weak, positive correlation between product innovation and the difficulty to enter new markets was found. This shows that the higher the importance of innovation is, the easier the entry to the main market was considered to be. This could be explained by the uniqueness and differentiation of innovative products, which can be appealing to new markets.

Product innovation and quality assurance systems are correlated, weakly but positively. This means the more important the product innovation is perceived to be the more important the quality assurance system is. This is because quality assurance systems provide a framework for product innovation.

There is a weak, positive correlation between product innovation and product awards in international competitions. This result shows, that the more important product innovation is considered, the more important product awards are perceived to be. This correlation might be explained because often, product awards are related to product innovation.

A weak, positive correlation between product innovation and income of target groups was found. The more important innovation is considered to be, the higher the target group's income is. An explanation is that innovative products very often have higher prices and aim at consumers of higher financial status. 


\section{Table 15. Product Innovation Correlations}

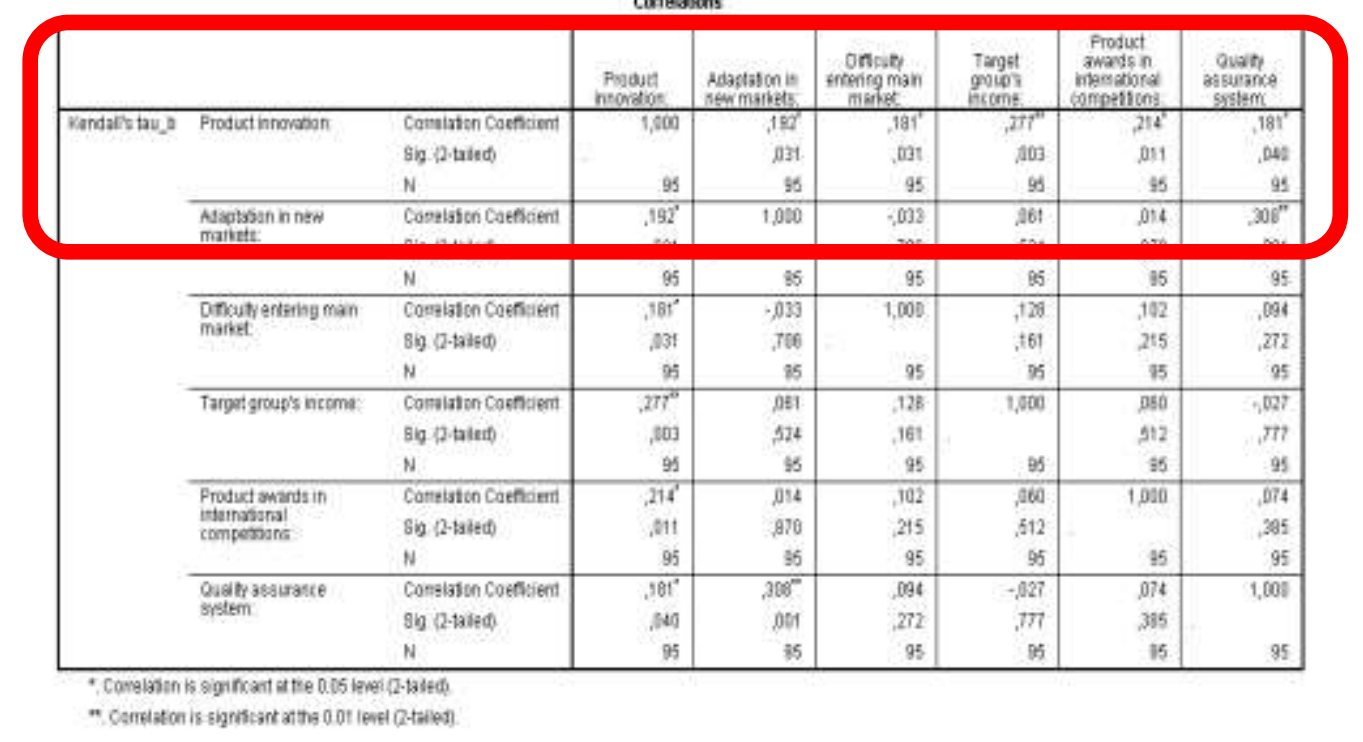

In regards to innovation and export performance no correlation was found in the case of Greek food and drink exporters, while the literature suggests that there is a positive relation between them. That could be due to the reason that Greek products exported are of a more "traditional character", or because exporters want to promote this traditional approach and are not investing to innovation.

\section{Conclusion}

The aim of this research is to examine the perception of the Greek food and drink exporters on the determinants of export success factors. We focus on the food and drink sector of Greece.

Firstly, the relation between the firm's size and export performance was examined. Prior results are contradictory since some suggest a positive relationship between size and export performance, while others argue that there is no significant relationship. Our findings indicate that there is no correlation between a firm's size and its export performance. This means that smaller Greek food and drink exporters are not limited by their firm's size to become successful exporters. This is of great practical importance for all the micro, small and medium sized businesses that plan to start export activities.

Next export experience was analyzed. Again, there is no agreement between researchers in regards to export performance and experience. The number of years firms have been active as exporters are used as the base to measure export 
experience (actual export experience). Regarding export experience, no correlation with export performance was found. However, there is a weak, positive correlation between the perceived importance of experience and export performance. A firm's experience, even if it is considered important, in reality is not a limiting factor for export success.

Another interesting finding was that older firms faced more difficulties to enter their main international markets than the younger ones did. Moreover, the income and socio-cultural level of the target groups appear to change. In the past, Greek firms aimed mainly at medium and low income and socio-cultural status consumers. On the contrary, younger exporting firms aim to consumers of high income level and socio-cultural status. This finding explains why there is no correlation between actual experience and export performance. The above suggest a change of the export approach/orientation of the Greek food and drink exporters.

Next, commitment to exports was examined. Commitment to exports is expressed by the firm's dependency on exports. There is a general agreement among researchers that being committed to exports has a positive impact on export performance. Our findings indicate a weak positive correlation between commitment to exports and export performance. Regarding export commitment, the existence of an export department is considered to be important. The results indicate that being committed to exports, is not just declaring it, but communication with trade partners, consistency in agreements with foreign trade partners and participation in international fairs, are elements of export commitment. However, this correlation was expected to be stronger.

The majority of researchers found a positive relation between product quality and export performance. However, some note that quality itself is not enough to enhance export performance, or that quality in some industries is unimportant. Our results indicate that there is no correlation between export performance and quality. Even though Greek exporters consider quality as being very important, quality by itself cannot guarantee or lead to export success.

Product quality is positively related to PGI and PDO schemes and quality assurance systems. A weak, positive correlation was found between quality and a) participation in international fairs, b) communication and c) consistency in agreements with trade partners. At the international trade fairs, quality can be the means for product promotion. Quality in the case of communication and consistency can be related to the product quality agreed with trade partners. All in all though, quality for the vast majority of respondents is considered very important, regardless export performance. There are contradictory findings regarding price and its relation to exports in literature. In this research no correlation was found between price and export performance. The current export approach is not price based. However, there is 
positive correlation between price and size as well years of actual export experience. As noted earlier, firms with different export experience target different target groups. In addition, older firms perceive price as more important. There is also a weak positive correlation between price and participation in international trade fairs. When potential trade partners meet, price plays an important role for business deals. Finally, there is a positive relation between price, perceived export experience and the existence of an export department. The knowledge gained through experience can lead to efficient price related strategies. The same applies for the existence of an export department.

The last variable examined was product innovation. According to literature findings, there is a positive relation between export performance and innovation, but we did not found a correlation. This can be because in the mind of international consumers, as well as exporters, the majority of Greek products have a traditional character and are not regarded as innovative.

Product innovation has a weak positive correlation with: quality assurance system, entry-market difficulty, new market adaptation, product awards and the target group's income. Quality assurance systems might be considered as innovation in certain markets, especially the latest types of ISO certificates related to environmental friendly practices. In many exhibitions many awards are related to product innovation, so a positive correlation is expected. Furthermore, firms that perceive product innovation as important seem to face fewer entry market barriers. Innovation can be the means to adapt to new export markets. Additionally, product innovation has a weak, positive correlation with the target group's income, meaning that the more innovative the product is, the higher the target group's income level is. To summarize, the firm's size and actual experience are not related to export performance, thus new firms that plan to start export activities should not perceive them as limitations.

Furthermore, product quality does not seem to have impact on export performance, but the vast majority of exporters consider it to be very important. Overall, price does not seem to be a hindering factor to export activities. Regarding innovation, no correlation was found with export performance. Firms do not necessarily have to invest heavily on innovation, but the ones' that do so, aim to higher income groups and find it easier to enter new markets. The most important barrier to export success according this research is not being highly committed to exports.

One of the limitations of this research is that it examines the overall food and drink exports; and not a specific subsector. In addition, many respondents provided in some questions similar answers, and this did not allow for a more advanced statistical analysis. The fact that qualitative variables were not used does not allow a more in depth analysis. 
The findings of this study provide a useful practical tool for food and drink producers that seek to begin exporting, as it provides insights from active exporters. Some findings should be further investigated, such as the change of the target market characteristics (sociocultural and economic level) and the role of price for young food and drink exporters. Finally, it is worth exploring if the attributes/practices that are considered to be important for export success are actually applied in the business activities of the Greek food and drink exporters.

\section{References}

Bizmpiroulas A \& Rotsios K 2014, The Greek Food Product Exports: Challenges and Opportunities. An interview with Mr. Dimitrios Lakasas, From Fork to Farm, Vol. 1, No. 1.

Boehe, D.M. \& Barin Cruz, L 2010, Corporate Social Responsibility, Product Differentiation Strategy and Export Performance, Journal of Business Ethics, Vol. 91, pp. 325-346.

Boso, N, Story, V, Cadogan, J, Micevski, M, \& Kadić-Maglajlić, S 2013, Firm Innovativeness and Export Performance: Environmental, Networking, and Structural Contingencies, Journal Of International Marketing, Vol. 21, No. 4, pp. 62-87.

Curzi, D, \& Olper, A 2012, Export behavior of Italian food firms: Does product quality matter?, Food Policy, Vol. 37, No 5, pp.493-503.

Diamantopoulos, A, and Kakkos, N 2007, Managerial Assessments of Export Performance: Conceptual Framework and Empirical Illustration, Journal of International Marketing, Vol. 15, No. 3 (2007), pp. 1-31.

European Commission 2014, What is a SME, viewed 27 May 2014, http://ec.europa.eu/enterprise/policies/sme/facts-figures-analysis/sme-definition/

Fisher, C 2010, Food Quality and Product Export Performance: An Empirical Investigation of the EU Situation, Journal of International Food \& Agribusiness Marketing, Vol. 22, No. 3-4, pp. 210-233.

Hajidimitriou, Y. 2003, International Business Practices, Anikoula, Thessaloniki, Greece

Hambrick D.C, Geletkanycz M.A, \& Fredrickson J.W 1993, Top Executive Commitment to the Status Quo: Some Tests of Its Determinants, Strategic Management Journal, Vol. 14, No. 6, pp. 401-418.

Lages, L, Silva, G, \& Styles, C 2009, 'Relationship Capabilities, Quality, and Innovation as Determinants of Export Performance', Journal of International Marketing, Vol. 17, No. 4, pp. 47-70.

Lages, L.F, Jap S. D, \& Griffith D. A 2008, The Role of Past Performance in Export Ventures: A Short-Term Reactive Approach, Journal of International Business Studies, Vol. 39, No. 2, pp. 304-325.

Larimo, J 2013, Small and Medium-Size Enterprise Export Performance, International Studies Of Management \& Organization, Vol. 43, No. 2, pp. 79-100.

Leonidou L, Katsikeas C \& Samiee S 2002, Marketing strategy determinants if export performance: a meta-analysis, Journal of Business Research, Vol. 55, No.1, pp. 51-67.

Majocchi, A, Bacchiocchi, E, \&Mayrhofer U 2005, Firm size, business experience and export intensity in SMEs: A longitudinal approach to complex relationships International Business Review, Volume 14, Issue 6, Pages 719-738 
Maurel, C 2009, Determinants of export performance in French wine SMEs, International Journal of Wine Business Research, Vol. 21, No 2, pp.118-142.

Mavrogiannis, M, Bourlakis, M, Dawson, P, \& Ness, M 2008, Assessing export performance in the Greek food and beverage industry-An integrated structural equation model approach, British Food Journal, Vol. 110, No. 7, pp. 638-654.

Nagy, G, \& Berács, J 2012, Antecedents to the export market orientation of Hungarian higher education institutions, and their export performance consequences, Journal of Marketing For Higher Education, Vol. 22, No. 2, pp. 231-256.

Navarro, A, Losada, F, Ruzo, E, \& Díez, J 2010, Implications of perceived competitive advantages, adaptation of marketing tactics and export commitment on export performance, Journal of World Business, Vol. 45, No1, pp.49-58.

Obadia, C 2013, Competitive Export Pricing: The Influence of the Information Context, Journal Of International Marketing, Vol. 21, No. 2, pp. 62-78.

Oliveira, J.S, Cadogan, J.W, \& Souchon, A 2012, "Level of analysis in export performance research", International Marketing Review, Vol. 29 No.1, pp.114-27.

Shinkle, G, \& Kriauciunas A 2010, Institutions, Size and Age in Transition Economies: Implications for Export Growth, Journal of International Business Studies, Vol. 41, No. 2, pp. 267-286.

Shoham, A 1998, Export Performance: A Conceptualization and Empirical Assessment, Journal of International Marketing, Vol. 6, No. 3, pp. 59-81.

Sousa, C. M.P, Martínez-López, F. J, \& Coelho, F 2008, The determinants of export performance: A review of the research in the literature between 1998 and 2005 . International Journal of Management Reviews, Vol. 10, No.4, pp. 343-374.

Stoian, M., Rialp, A. \& Rialp, J 2011. Export performance under the microscope: A glance through Spanish lenses, International Business Review, Vol. 20, No. 2, pp.117-135.

Zaiem, I, and Zghidi A. B. Y 2011, Product Adaptation Strategy and Export Performance: The Impacts of the Internal Firm Characteristics and Business Segment, Contemporary Management Research, Vol.7, No.4, Pages 291-312. 